Germanies' environmental agreement

\section{Munich}

West Berliners and West Germans now have grounds to hope for relief from the clouds of coal smoke wafting over from East Germany. With the initialling of an East/West German environmental agreement in Bonn on 10 June, the two governments have agreed to work together on reducing air and water pollution and minimizing damage to forests. The pact will be signed during the still-speculative visit later this year of Erich Honecker, general secretary of East Germany's Communist Party, to West Germany.

The environmental agreement with East Germany is just the latest in a series of arrangements between West Germany and Soviet bloc countries in 1987. It follows agreements on nuclear power, health and environment made with the Soviet Union in March and April. Long-awaited pacts between East and West Germany on scientific cooperation and nuclear power are expected to be signed soon.

One important political hurdle cleared in these latest negotiations is the inclusion of the West German Umweltbundesamt (Federal Environmental Office or UBA), an institute in West Berlin; East Germany has agreed for the first time that researchers at the UBA may participate in collaborative projects, even though the East German government does not accept the location of the institute in West Berlin, still officially administered by the four powers victorious in the Second World War. As in the nuclear agreement with the Soviets, negotiators agreed upon the socalled ad personam solution in which conference invitations to West Berlin researchers are addressed to them privately.

Researchers from the two states will meet regularly over the next three years to discuss ways to reduce emissions containing sulphur dioxide and nitrogen oxides. East Germany is particularly dependent on pollution-intensive high-sulphur brown coal and faces costs of millions of West German marks to refit their power plants or use other energy sources.

The onus is now on West Germany to provide hard currency for these conversions, which are already technically possible. Sources in several ministries said that there are no plans for financial help on a grand scale, but West German finance minister Martin Bangemann (Free Democrat) has mentioned more than once the willingness of West German companies to offer to East Germany free pilot projects in power generation and smoke clean-up. These projects are one step closer to realization. Steven Dickman

\title{
Animal patent dispute out in the open at congressional hearings
}

\section{Washington}

Groups demanding legislation to reverse the US Patent and Trademark Office's controversial decision to permit the patenting of genetically engineered animals had a first chance to air their views at a congressional hearing last week. They responded with vigorous objections to the Patent Office decision, on both ethical and economic grounds.

In its evidence to the subcommittee on courts, civil liberties and the administration of justice, the Patent Office stuck to the position that the decision it took in April (see Nature 326, 729; 1987) was not a determination of public policy. All that had been done, Assistant Commissioner for Patents Rene Tegtmeyer argued, was to implement the decision, made seven years earlier by the Supreme Court in the case of Diamond versus Chakrabarty, that under the Sun made by man". That decision did not "leave much room to refuse to consider living things as patentable subject matter if they were a product of human intervention".

An animal welfare group, the Humane Society, was more concerned with broad ethical principles than legal history. Its view is that the patenting of life "violates the basic ethical precepts of civilized society and unleashes the potential for patent matter was to "include anything

uncontrollable and unjustified animal suffering".

Perhaps more telling was the Humane Society's argument, amplified by others, that the patenting of animal models would encourage a competitive rather than a collaborative research atmosphere to "the ultimate detriment of the public's best interests". Costly research would be duplicated and scientific progress be inhibited. In the end, according to environmental groups represented at the hearing, that would mean that only big companies would be able to keep going. Farmers, reliant on them for the supply of more productive animals, would be forced to pay higher prices which would be passed on to the consumer. The corporations would get rich quick while everyone else would suffer. And, the League of Rural Voters pointed out, that would transfer power over agriculture from the nation's farmers to giant agribusiness.

Biotechnology industry representatives did not agree. They saw the granting of patents as an enormous stimulus that would revitalize research and add massively to the varieties offered to the farmer. In biotechnology, small companies are still the rule and investors would be more likely to come forward if they knew that new products could be patented.

Alun Anderson

\section{TPA patent battle continues in court}

\section{London}

THE spotlight remains focused on proceedings in London's High Court this week, as the UK drug company Wellcome continues its legal efforts to see the revocation of Britain's first biotechnology patent, held on the production of tissue plasminogen activator (TPA) by the US group Genentech (see Nature 327, 450; 1987).

As the case moved into its second week, Genentech lawyers began cross-examining some of the scientists who had provided testimony on behalf of Wellcome. First on the stand was Joe Sambrook, who was at the Cold Spring Harbor Laboratory when he initiated the work that led, by a complex series of events, to Wellcome's process for making TPA. He was followed by MaryJane Gething, who now works with Sambrook at the University of Texas Health Science Center in Dallas, Tim Harris of Celltech, which has an independent interest in TPA, and Tom Maniatis of Harvard University but also a founder of Genetics Institute, to which Sambrook turned for collaboration at one stage.

Wellcome seeks to prove that Genentech's process of cloning TPA DNA was not sufficiently novel or inventive to establish patentability, but is instead 'obvious'. Wellcome is a rival to Genentech in the production of TPA, a clot-dissolving drug with the potential for enormous sales. Wellcome is also arguing that the patent as issued covers all methods of producing TPA and as such is far too broad.

Genentech is expected to start producing its witnesses and evidence later this week, with the court case scheduled to continue all next week. Genentech's case will be aimed at proving that its biotechnological clone is novel and therefore patentable. Senior scientists at the company went into retreat to read about 400 papers and establish their case.

Before the court are stacks of thick files with reports and papers, all carefully arranged - but the profusion of paper often leads to confusion as a witness is asked to turn, for example, to "Bundle $\mathbf{3}$, Tab $\mathbf{H}$, second page, fifth paragraph, last sentence". After the first week of the case, the judge remarked ruefully that "there must be more papers on TPA than there are authorities on obviousness".

Kathy Johnston 